\title{
Metabolic aspects of pig-to-monkey (Macaca fascicularis) islet transplantation: implications for translation into clinical practice
}

\author{
A. Casu $\cdot$ R. Bottino $\cdot$ A. N. Balamurugan $\cdot$ H. Hara \\ D. J. van der Windt $\cdot$ N. Campanile $\cdot$ C. Smetanka • \\ D. K. C. Cooper • M. Trucco
}

Received: 19 June 2007 / Accepted: 30 August 2007 / Published online: 25 October 2007

(C) Springer-Verlag 2007

\begin{abstract}
Aims/hypothesis Attempts to use an alternative source of islets to restore glucose homeostasis in diabetic patients require preclinical islet xenotransplantation models to be tested. These models raise questions about metabolic compatibility between species and the most appropriate metabolic parameters to be used to monitor graft function. The present study investigated and compared relevant gluco-metabolic parameters in pigs, monkeys and the pig-to-monkey islet transplantation model to gain insight into the potential clinical outcome of pig-to-human islet transplantation.

Methods Basal and IVGTT-stimulated blood glucose, Cpeptide, insulin and glucagon levels were assessed in nondiabetic pigs and monkeys. The same parameters were used to evaluate the performance of porcine islet xenografts in diabetic monkeys.

Results Non-diabetic cynomolgus monkeys showed lower levels of fasting and stimulated blood glucose but higher levels of C-peptide and insulin than non-diabetic pigs. The
\end{abstract}

A. Casu and R. Bottino contributed equally to this study.

A. Casu $(\bowtie) \cdot$ R. Bottino $\cdot$ A. N. Balamurugan •

D. J. van der Windt $\cdot$ N. Campanile $\cdot$ M. Trucco

Division of Immunogenetics, Department of Pediatrics,

Children's Hospital of Pittsburgh, Rangos Research Centre,

Rm 6103, 3460 Fifth Avenue,

Pittsburgh, PA 15213, USA

e-mail: anc22@pitt.edu

A. N. Balamurugan $\cdot$ H. Hara $\cdot$ N. Campanile $\cdot$ C. Smetanka

D. K. C. Cooper

Thomas E. Starzl Transplantation Institute,

University of Pittsburgh,

Pittsburgh, PA, USA reported levels in humans lie between those of monkeys and pigs, and differences in metabolic parameters between pigs and humans appear to be smaller than those between pigs and cynomolgus monkeys. The transplantation data indicated that the degree of graft function (evaluated by the measurement of C-peptide levels) necessary to normalise blood glucose in the recipient was determined by the recipient levels rather than by the donor levels.

Conclusions/interpretation The differences between donor and recipient species may affect the transplantation outcome and need to be considered when assessing graft function in xenotransplantation models. Given the differences between monkeys and humans as potential recipients of pig islets, it should be easier to reach glucose homeostasis in pig-to-human than in pig-to-non-human primate islet xenotransplantation.

Keywords Diabetes · Non-human primates . Pancreatic islets $\cdot$ Pigs $\cdot$ Xenotransplantation

\begin{tabular}{|c|c|}
\hline Abbreviations & \\
\hline $\mathrm{ACR}_{\text {Arg }}$ & $\begin{array}{l}\text { acute C-peptide response after } \\
\text { arginine }\end{array}$ \\
\hline $\mathrm{AIR}_{\mathrm{Arg}}$ & $\begin{array}{l}\text { acute insulin response after } \\
\text { arginine }\end{array}$ \\
\hline AST & arginine stimulation test \\
\hline GGTA1-DKO & GGTA1 double-knockout \\
\hline & glucose disappearance rate \\
\hline MMT & mixed meal test \\
\hline
\end{tabular}

Introduction

Despite the partial success of clinical islet allotransplantation in long-term follow-up, patients with type 1 diabetes 
may benefit from islet cell replacement therapy [1]. If less aggressive yet effective immunosuppressive protocols were found, islet transplantation could become a valid therapeutic alternative to insulin injections. The source of human islets for transplantation, however, remains limited. The use of animal islets, such as from the pig, offers a possible alternative that deserves consideration. As a preclinical experimental model, pig islet transplantation in non-human primate recipients is currently under investigation by different groups [2-4].

Intraportal injection of porcine islets, as recently reported by the groups of Larsen and Hering, allows a period of insulin independence in immunosuppressed diabetic monkey recipients [2, 3]. This model represents a good prototype to study the immunological aspects of islet xenotransplantation. However, as islet recipients, monkeys, in particular cynomolgus monkeys (Macaca fascicularis), display metabolic peculiarities which are only partially characterised [5-8]. Pigs, as a source of islet grafts, show a metabolic performance in vivo and in vitro which differs dramatically from that of monkeys [9-11]. These differences should be taken into consideration when engaging in xenotransplantation studies.

Successful pig-to-monkey islet xenotransplantation makes it possible to investigate how these differences influence the glucose metabolism of this combined model and to directly assess the behaviour of islets characterised by different functionalities within their physiological environment.

The aims of the present study were to define the metabolic compatibility between pigs and cynomolgus monkeys, to determine how it influences the pig-to-monkey islet transplantation model, and, more importantly, to help predict the performance of the islet graft based on the recipient's metabolic demand. Our data suggest that xenogeneic pig-to-human grafting has greater potential for success than pig-to-cynomolgus monkey grafting.

\section{Methods}

Animals Twenty healthy male cynomolgus monkeys (Macaca fascicularis; Spring Scientific, Perkasie, PA, USA), 2-4 years of age and weighing 2.4-4.7 kg (median $3.6 \mathrm{~kg}$ ), were studied. Catheters were placed into the jugular vein, carotid artery and stomach.

Seven wild-type outbred Large White female pigs (Wally Whippo, Enon Valley, PA, USA), 2-3 months of age and weighing 12-35 kg (median $24 \mathrm{~kg}$ ) were used for metabolic studies. Two jugular vein catheters were placed for blood withdrawal and drug infusion.

For islet isolation we used pancreases from wild-type large white adult female pigs (Wally Whippo) and adult female pigs that were double-knockouts for GGTA1, which encodes $\alpha 1$, 3-galactosyltransferase gene (GGTA1-DKO pigs; Revivicor, Blacksburg, VA, USA) [12], all weighing $>180 \mathrm{~kg}$.

All procedures were in accordance with the Principles of Laboratory Animal Care (National Society for Medical Research) and the Guide for the Care and Use of Laboratory Animals (NIH publication No. 86-23, revised 1985), and were approved by the University of Pittsburgh Animal Care and Use Committee.

Metabolic parameters Blood glucose $(\mathrm{mmol} / \mathrm{l})$ was measured in whole blood with a portable glucometer (Freestyle; Abbott Laboratories, Abbott Park, IL, USA). Serum levels of porcine and primate C-peptide (nmol/l) were measured by radioimmunoassay (Linco Research, St Charles, MO, USA) using species-specific antibodies. Aprotinin 0.05 kIU/l (Trasylol; Bayer Pharmaceuticals, West Haven, CT, USA) was added at the time of sampling. Primate and porcine insulin levels $(\mathrm{pmol} / \mathrm{l})$ in plasma or serum were measured by ELISA using species-specific assays (Mercodia, Uppsala, Sweden). Glucagon (pmol/l) was measured in serum by radioimmunoassay (Linco Research).

To summarise the metabolic status of each monkey before induction of diabetes, after induction of diabetes, and after islet transplantation until euthanasia or until vascular catheters were removed (8-120 days after transplantation), we recorded (1) mean blood glucose ( $\mathrm{mmol} / \mathrm{l})$; (2) the prevalence of blood glucose readings $>11.1 \mathrm{mmol} / 1(\%)$; (3) the mean exogenous insulin requirement $\left(\mathrm{IU} \mathrm{kg}^{-1} \mathrm{day}^{-1}\right)$; and (4) mean porcine C-peptide levels.

Intravenous glucose tolerance test After an overnight fast, $0.5 \mathrm{~g} / \mathrm{kg}$ of a $25 \%$ dextrose solution was infused i.v. over $1 \mathrm{~min}$. Blood glucose was measured in the monkeys before and 2, 5, 15, 30, 60 and 90 min after infusion. Insulin, Cpeptide and glucagon were measured before and 5, 15 and 90 min after infusion. In the pigs, blood glucose, C-peptide, insulin and glucagon were measured before and 5, 15, 30, 60 and 120 min after glucose infusion.

IVGTTs were performed in seven non-diabetic monkeys, five diabetic monkeys, four diabetic monkey recipients of functional porcine islet grafts, and seven non-diabetic pigs. The glucose disappearance rate $\left(K_{\mathrm{G}}\right)$, which represents the $\log$-linear $(\ln )$ decline in the glucose level during the first $30 \mathrm{~min}$ of the IVGTT, was calculated using the following formula [13]:

$$
\begin{aligned}
K_{\mathrm{G}}= & {[\ln (\text { glucose level at } 5 \mathrm{~min})-\ln (\text { glucose level at } 30 \mathrm{~min}) / 25] } \\
& \times 100 .
\end{aligned}
$$

The mean of the ratios between C-peptide and insulin values at 5 and $15 \mathrm{~min}$ was expressed as a fold increase over the prechallenge value (time 0 ). 
Oral glucose tolerance test Tests were performed in eight non-diabetic and two diabetic monkeys. After an overnight fast, $2 \mathrm{~g} / \mathrm{kg}$ of glucose in a $50 \%$ dextrose solution was administered through the indwelling gastric catheter. Blood glucose was measured before and 15, 30, 60 and $90 \mathrm{~min}$ after the infusion. Primate C-peptide, insulin and glucagon were measured before and 15,30, and $90 \mathrm{~min}$ after glucose infusion.

Arginine stimulation test Arginine stimulation tests (ASTs) were performed in seven non-diabetic and seven diabetic monkeys. After an overnight fast, $70 \mathrm{mg} / \mathrm{kg}$ of $10 \%$ arginine solution (Pharmacia \& Upjohn Company, Kalamazoo, MI, USA) was administered and i.v. samples were drawn before and 2, 3, 4 and $5 \mathrm{~min}$ after the infusion for measurement of blood glucose, C-peptide, insulin and glucagon levels. The acute insulin response $\left(\mathrm{AIR}_{\mathrm{Arg}}\right)$ and the acute $\mathrm{C}$-peptide response $\left(\mathrm{ACR}_{\mathrm{Arg}}\right)$ after the arginine stimulus were calculated as the difference between the mean at 2, 3, 4 and 5 min after stimulus and the corresponding prechallenge value of C-peptide and insulin $[14,15]$.

Mixed meal test Mixed meal tests (MMTs) were performed in three non-diabetic and three diabetic monkeys. After an overnight fast, a mixed meal (four Purina biscuits + half an apple [carbohydrate $30 \mathrm{~g}$, fat $4 \mathrm{~g}$, protein $6 \mathrm{~g}$ ]) was administered orally, and serum samples were taken before and 60 and $120 \mathrm{~min}$ after the meal for determination of blood glucose, C-peptide, insulin and glucagon levels.

Induction of diabetes Diabetes was induced in ten monkeys by i.v. injection of streptozotocin 125-150 mg/kg (Zanosar; Sicor Pharmaceuticals, Irvine, CA, USA) in a single dose, as described in [16].

Diabetes was confirmed by persistent hyperglycaemia ( $>11.1 \mathrm{mmol} / \mathrm{l}$ on at least two occasions) and by the need for insulin to prevent ketosis [17]. IVGTTs, OGTTs, ASTs and MMTs were performed 8-35 days (median 11 days) after induction of diabetes. Immunohistochemical analyses of pancreatic sections from four diabetic monkeys showed $<1 \%$ of insulin-positive cells compared with $\sim 70 \%$ of insulin-positive cells in healthy controls, as reported previously [16].

Diabetic monkeys were treated by continuous i.v. infusion of insulin (Humulin R; Eli Lilly, Indianapolis, IN, USA) to maintain the blood glucose level $<11.1 \mathrm{mmol} / 1$ and to prevent the development of ketosis. Insulin therapy was stopped $1.5 \mathrm{~h}$ before stimulation tests.

Porcine islet isolation and transplantation into monkeys Nine monkeys underwent porcine islet transplantation. Porcine islets were isolated and purified according to a standard procedure that involved low enzyme concentration, low digestion temperature and minimal mechanical digestion [18]. The overall quality of the islet preparations was evaluated as described in [18]: viability was $>95 \%$, purity $82.1 \pm 4.5 \%(n=5)$ islets/whole tissue, and the mean stimulation index was $4.6 \pm 1.7(n=5)$. A total of 40,000 100,000 islet equivalents (IEq) $/ \mathrm{kg}$ was infused into the portal vein under direct vision at laparotomy under general anaesthesia. Transplantation was performed at least 2 weeks after diabetes induction (range 15-71 days, median 22 days). Insulin infusion was discontinued $2 \mathrm{~h}$ before islet infusion. In three monkeys (monkeys 8, 9 and 10), insulin was administered at $0.03-0.06 \mathrm{IU} \mathrm{kg}^{-1} \mathrm{~h}^{-1}$ for $3 \mathrm{~h}$ after meals for 2 weeks following islet transplantation to minimise metabolic stress of the graft. Continuous insulin infusion was restored if blood glucose was consistently $>11.1 \mathrm{mmol} / \mathrm{l}$.

The immunosuppressive regimen was based on antithymocyte globulin (Thymoglobulin; Genzyme Polyclonals, Lyon, France; $10 \mathrm{mg} / \mathrm{kg}$ i.v. on days -3 and -1 ), costimulatory blockade with a humanised anti-CD154 monoclonal antibody (ABI 793, a gift from Novartis, Basel, Switzerland; $25 \mathrm{mg} / \mathrm{kg}$ i.v. at days $-1,0,4,7,10$ and 14 and then every 5-7 days), and mycophenolate mofetil (Cellcept i.v. or oral suspension; Roche Laboratories, Nutley, $\mathrm{NJ}$; 75-150 $\mathrm{mg} \mathrm{kg}^{-1}$ day $^{-1}$ i.v. or twice daily orally beginning on day -4 ), as previously described [4]. They also received dextran sulphate (Fluka Chemie, Buchs, Switzerland) $2 \mathrm{mg} / \mathrm{h}$ for $5 \mathrm{~h}$ after transplantation, aspirin $40 \mathrm{mg} / \mathrm{kg}$ every other day, and prostacyclin (Flolan; GlaxoSmithKline, Research Triangle Park, NC, USA) $20 \mathrm{mg} \mathrm{kg}^{-1} \min ^{-1}$ for $5 \mathrm{~h}$ after transplantation.

Islet graft function was monitored by measuring porcine C-peptide. An IVGTT was also performed in monkeys that showed an improvement in metabolic control 2 weeks after transplantation or when the clinical condition of the animal allowed it (range 14-45 days after transplantation, median 27 days).

Statistical analyses Experimental data are presented as means \pm SE. Human data obtained from the literature are presented as the range of values or mean of the published data $[19,20]$. Student's $t$ test was used to compare means. For ease of comparison, human data obtained from the literature are reported in the "Results" section rather than in the "Discussion".

\section{Results}

Comparison of metabolic parameters between non-diabetic monkeys and pigs Fasting blood glucose, C-peptide, insulin 
Table 1 Fasting blood glucose, C-peptide, insulin and glucagon levels in monkeys, pigs and humans

\begin{tabular}{llll}
\hline & Cynomolgus monkeys & Pigs & Humans \\
\hline Blood glucose (mmol/1) & $2.2-4.1(3.2 \pm 0.1, n=29)^{\mathrm{a}}$ & $4.0-5.2(4.8 \pm 0.2, n=7)$ & $3.9-5.6[20]$ \\
C-peptide (nmol/l) & $0.47-3.14(1.39 \pm 0.09, n=37)^{\mathrm{a}}$ & $0.11-0.32(0.16 \pm 0.04, n=5)$ & $0.17-0.66[19]$ \\
Insulin (pmol/l) & $15-201(109 \pm 11, n=27)^{\mathrm{b}}$ & $7-12(9 \pm 1, n=3)$ & $34-138[19]$ \\
Glucagon $(\mathrm{pmol} / \mathrm{l})$ & $18.7-179.4(54.3 \pm 6.9, n=27)^{\mathrm{a}}$ & $11.3-13.8(12.5 \pm 1.0, n=3)$ & $5.7-28.7[19]$ \\
\hline
\end{tabular}

Data are ranges, with means $\pm \mathrm{SE}$ and number of measurements in parentheses. Human data were obtained from the literature and were measured in venous plasma $[19,20]$. C-peptide, insulin and glucagon levels in monkeys were significantly higher than corresponding levels in the pig, while blood glucose levels in monkeys were significantly lower than those in pigs (monkey vs pig, ${ }^{\mathrm{a}} p<0.001 ;{ }^{\mathrm{b}} p=0.021$ )

and glucagon values in monkeys, pigs and humans are presented in Table 1. Blood glucose in fasting non-diabetic monkeys ranged from 2.2 to $4.1 \mathrm{mmol} / 1$ and was significantly lower than the corresponding values in pigs (4.0-5.2 mmol/1; $p<0.001)$. Mean serum C-peptide and insulin values in monkeys were ten times higher than in pigs (C-peptide, $1.39 \pm 0.09 \mathrm{nmol} / \mathrm{l}$ in monkeys vs $0.16 \pm$ $0.04 \mathrm{nmol} / \mathrm{l}$ in pigs, $p<0.001$; insulin, $109 \pm 11 \mathrm{pmol} / 1$ in monkeys vs $9 \pm 1 \mathrm{pmol} / 1$ in pigs, $p=0.01)$. Fasting glucagon values were significantly higher $(p=0.001)$ in monkeys (18.7-179.4 pmol/1) compared with pigs (11.3-13.8 pmol/1).

The data for healthy monkeys were also compared with the human data to better characterise similarities and differences that may help in predicting the metabolic performance of pig islets if considered for xenotransplantation in humans, even though the comparisons are limited by the difference in the testing conditions. Human fasting blood glucose values (Table 1) [20] appeared to be higher than those in monkeys, even after correction for the type of sample tested (i.e. whole blood in monkeys and plasma in humans) [21-23]. Human C-peptide [19] were consistently lower than monkey C-peptide levels and resembled the values seen in the pigs. The range of human glucagon levels [19] was lower than that in the monkeys, and again more closely resembled levels in the pigs.

Figure 1 shows the differences in blood glucose, Cpeptide, insulin and glucagon values between monkeys and pigs after an i.v. glucose stimulus. Elicited insulin secretion was able to reduce blood glucose values in both monkeys and pigs (Fig. 1a). However, after the initial rise, blood glucose fell more slowly in pigs than in monkeys, as indicated by lower $K_{\mathrm{G}}$ values [monkeys, 3.27-8.22 $\mathrm{mmol} \mathrm{l}^{-1} \mathrm{~min}^{-1}$ (mean $6.17 \mathrm{mmol} \mathrm{l}^{-1} \mathrm{~min}^{-1}$ ); pigs, 2.75-6.70 $\mathrm{mmol} \mathrm{l}^{-1} \mathrm{~min}^{-1}$ (mean $3.64 \mathrm{mmol} \mathrm{l}^{-1} \mathrm{~min}^{-1}$ ); $p=0.04$ ].

As expected, the absolute C-peptide and insulin-stimulated values were higher in monkeys (mean at $5 \mathrm{~min}$ : C-peptide $3.12 \pm 0.55 \mathrm{nmol} / 1$, insulin $706 \pm 164 \mathrm{pmol} / \mathrm{l}$ ) than in pigs (mean at $5 \mathrm{~min}$ : C-peptide $0.46 \pm 0.03 \mathrm{nmol} / \mathrm{l}$, insulin $25 \pm 6 \mathrm{pmol} / \mathrm{l}$; Fig. 1b,c).

Nevertheless, the fold increases in C-peptide between time 0 and $5 \mathrm{~min}$ and between time 0 and $15 \mathrm{~min}$ were

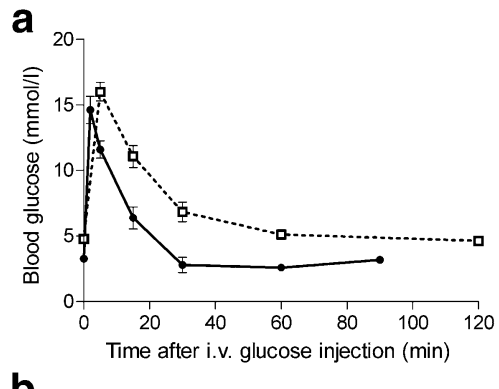

b

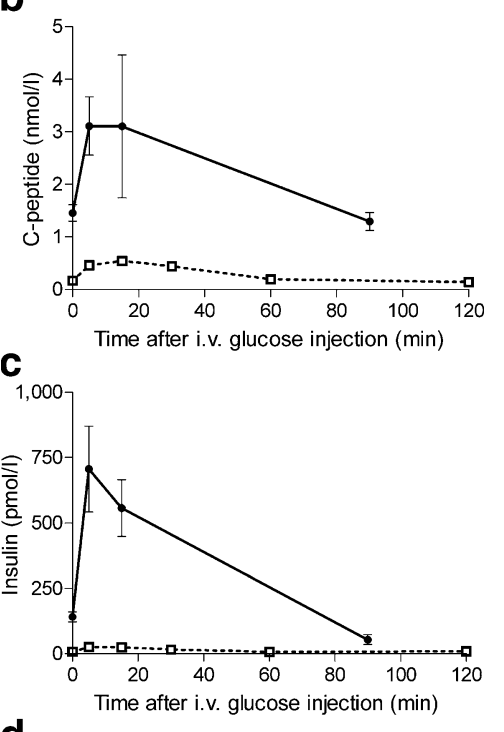

d

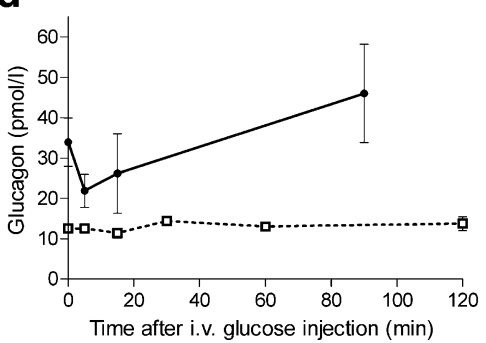

Fig. 1 Comparison of metabolic parameters during IVGTT between healthy non-diabetic monkeys and pigs. Mean \pm SE of blood glucose (a), C-peptide (b), insulin (c) and glucagon (d) during an IVGTT in non-diabetic monkeys (solid lines) and non-diabetic pigs (broken lines). (The SE is too small to be seen in the figure if below $10 \%$ of the mean value). Blood glucose concentrations decreased faster in monkeys than in pigs. The C-peptide and insulin concentrations after the stimulus were significantly higher in monkeys than in pigs 
respectively $3.2 \pm 0.5$ and $3.9 \pm 0.7$ in pigs, $2.4 \pm 0.8$ and $2.9 \pm$ 1.2 in monkeys (Fig. 1b). The fold increases in insulin between time 0 and $5 \mathrm{~min}$ and between time 0 and $15 \mathrm{~min}$ were $3.5 \pm 0.7$ and $2.9 \pm 0.7$ in pigs, $5.6 \pm 1.8$ and $4.8 \pm 2.1$ in monkeys (Fig. 1c).

Published data on IVGTTs performed in humans after i.v. injection of glucose at 0.3 or $0.5 \mathrm{~g} / \mathrm{kg}$ showed C-peptide and insulin levels intermediate between those of pigs and monkeys. The fold increases between time 0 and $5 \mathrm{~min}$ and between time 0 and 15 min were (range) $2.5-3.5$ and 2.13.0 respectively for C-peptide and 6.3-11.4 and 4.0-5.0 for insulin [24-30].

In both monkeys and pigs, glucagon fell after the stimulus (Fig. 1d); the fall was more pronounced in monkeys than in pigs.

Comparison of metabolic parameters between non-diabetic and diabetic monkeys The metabolic profile of the streptozotocin-treated monkeys was compared with that obtained before streptozotocin treatment. As expected, during the IVGTT the peak glucose concentration was significantly higher ( $p=0.03,2 \mathrm{~min}$ after glucose infusion) in diabetic monkeys than in non-diabetic monkeys (Fig. 2a). Thereafter, the glucose levels decreased at a slower rate in diabetic than in non-diabetic monkeys, as shown by the lower $K_{\mathrm{G}}$ (mean $1.01 \pm 0.12 \mathrm{mmol} \mathrm{l}^{-1} \min ^{-1}, p<0.001$ ). The Cpeptide increase, seen in non-diabetic monkeys, was absent in diabetic monkeys, with a slight fall 5 and 15 min after the glucose stimulus (Fig. 2b).

During the OGTT in non-diabetic monkeys, the increase in blood glucose was minimal (mean $4.3 \pm 0.4 \mathrm{mmol} / \mathrm{l}$ at $15 \mathrm{~min}$ ), whereas blood glucose continued to rise in diabetic monkeys (Fig. 2c). In the non-diabetic monkeys, C-peptide (Fig. 2d) and insulin (not shown) reached a maximum at $30 \mathrm{~min}$ (C-peptide $2.71 \pm 0.45 \mathrm{nmol} / \mathrm{l}$, insulin $571 \pm 158 \mathrm{pmol} / \mathrm{l})$, whereas there was no significant increase in diabetic monkeys. From the literature, C-peptide and insulin concentrations following stimulation in non-diabetic humans [31] are not very different from those detected in non-diabetic monkeys. In non-diabetic monkeys, the glucagon response was the mirror image of the C-peptide and insulin responses, with the lowest point at $30 \mathrm{~min}(25.1 \pm$ $9.2 \mathrm{pmol} / \mathrm{l}$; not shown).

During the AST in non-diabetic monkeys (Fig. 2e,f), blood glucose remained stable while C-peptide (as insulin and glucagon) values rose at $2 \mathrm{~min}$ and then returned to prestimulus values at $5 \mathrm{~min}$. The $\mathrm{AIR}_{\mathrm{Arg}}$ ranged from 57 to $328 \mathrm{pmol} / \mathrm{l}$ and the $\mathrm{ACR}_{\mathrm{Arg}}$ ranged from 0.20 to $0.89 \mathrm{nmol} / \mathrm{l}$. Published data show that the human $\mathrm{AIR}_{\mathrm{Arg}}$ is higher than the monkey $\mathrm{AIR}_{\mathrm{Arg}}$, whereas $\mathrm{ACR}_{\mathrm{Arg}}$ is similar to that in monkeys; however, the absolute basal and stimulated values are lower in humans than in monkeys [15, 32, 33]. In diabetic monkeys during the AST, blood glucose remained
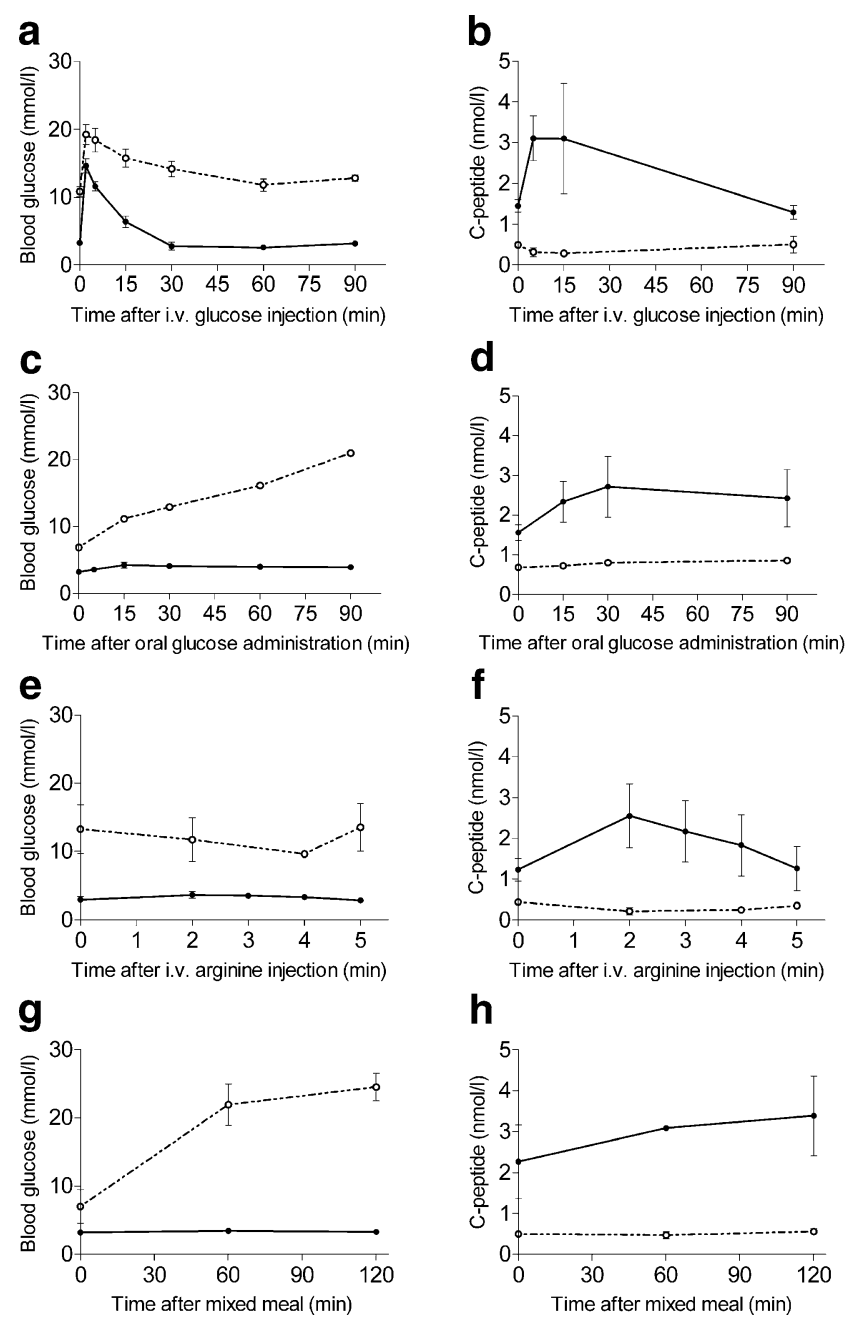

h

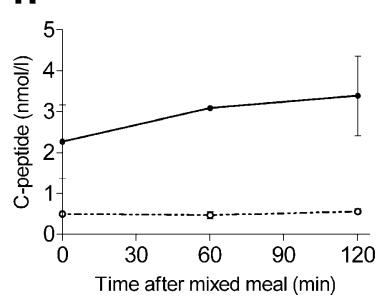

Fig. 2 Comparison of metabolic parameters between non-diabetic and diabetic monkeys. Mean \pm SE of blood glucose levels (a, c, e, g) and primate C-peptide levels (b, d, f, h) during IVGTT (a, b), OGTT (c, d), $\operatorname{AST}(\mathbf{e}, \mathbf{f})$ and MMT $(\mathbf{g}, \mathbf{h})$ in non-diabetic (solid lines) and diabetic (broken lines) monkeys. (SE was not calculated when fewer than three measurements were available). The primate $\mathrm{C}$-peptide response to physiological stimuli was completely abolished in diabetic monkeys, and this was associated with a prolonged increase in the blood glucose level

stable at approximately $13.9 \mathrm{mmol} / \mathrm{l}$ and C-peptide showed no response $\left(\mathrm{ACR}_{\mathrm{Arg}}-0.40-0.02 \mathrm{nmol} / \mathrm{l}\right)$.

During the MMT (Fig. 2g,h), in non-diabetic monkeys blood glucose was stable and C-peptide and insulin (not shown) rose slowly, with a peak $120 \mathrm{~min}$ after the meal $(3.39 \pm 0.97 \mathrm{nmol} / 1$ and $611 \pm 253 \mathrm{pmol} / 1$, respectively). In diabetic monkeys, blood glucose rose to its highest value $(24.5 \pm 2.0 \mathrm{mmol} / \mathrm{l}) 120 \mathrm{~min}$ after the meal. No increase in monkey C-peptide was seen. In non-diabetic humans, data from the literature show that mean insulin and C-peptide values after meals increase but correspond to lower values in non-diabetic monkeys [31, 33, 34]. 
In summary, following streptozotocin treatment in monkeys blood glucose levels increased above $15 \mathrm{mmol} / \mathrm{l}$ and fasting levels of endogenous $\mathrm{C}$-peptide declined to values corresponding to $12-33 \%$ of the C-peptide levels before diabetes induction. Insulin was needed to maintain blood glucose $<11 \mathrm{mmol} / \mathrm{l}$ and to prevent ketosis. Any residual endogenous C-peptide did not respond to physiological stimuli, as shown by the results of the dynamic tests and by the absence of correlation between endogenous C-peptide and blood glucose levels at the times of sampling. Furthermore, while attempting to maintain blood glucose $<11 \mathrm{mmol} / \mathrm{l}$ in diabetic monkeys, no correlation was found between endogenous C-peptide levels and the mean daily requirement of exogenous insulin per $\mathrm{kg}$ of body weight (data not shown).

Metabolic parameters in diabetic monkeys following porcine islet transplantation Following porcine islet transplantation, five monkeys (monkeys 2, 7, 8, 9 and 10) improved their metabolic control of glucose (Tables 2 and 3). This was defined as a mean blood glucose level of $<8.9 \mathrm{mmol} / 1$ accompanied by a reduction in the requirement for exogenous insulin therapy $\left(\leq 0.50 \mathrm{IU} \mathrm{kg}^{-1}\right.$ day $\left.^{-1}\right)$. In two of the five monkeys (monkeys 8 and 10), insulin therapy was unnecessary for 34 and 16 days, respectively. On average, porcine Cpeptide during the follow-up period after islet transplantation (8-120 days) in these five monkeys was $>0.20 \mathrm{nmol} / \mathrm{l}$.

Figure $3 \mathrm{a}$ shows the porcine C-peptide levels in monkeys with improved metabolic control compared with those that did not experience any improvement. The porcine Cpeptide values were mainly above the established threshold of $0.20 \mathrm{nmol} / 1$. Similarly, the daily insulin requirement in monkeys that had a mean porcine C-peptide level
$>0.20 \mathrm{nmol} / 1$ was below the threshold of $0.50 \mathrm{IU} \mathrm{kg} \mathrm{kg}^{-1}$ day $^{-1}$ (Fig. 3b). In the monkeys that experienced an improvement in metabolic control, the exogenous insulin requirement was reduced to less than half of that necessary before islet transplantation (Tables 2 and 3). In contrast, the insulin requirement remained stable or increased in those that did not show improved metabolic control (1.2- to 5.2fold increase compared with before transplantation). Any increase in requirement may have been associated with the stress induced by the surgical procedure and the immunosuppressive therapy. Monkey 1, with only a partial improvement in metabolic parameters (mean blood glucose $10.9 \mathrm{mmol} / \mathrm{l}$, mean porcine C-peptide $0.18 \mathrm{nmol} / \mathrm{l}$ ) had a reduction in mean insulin requirement to $52 \%$ of the pretransplantation requirement $\left(1.38 \mathrm{IU} \mathrm{kg}^{-1} \mathrm{day}^{-1}\right.$ ).

The monkeys with improved metabolic control also demonstrated more stable glucose values, as indicated by a lower frequency of blood glucose levels $>11 \mathrm{mmol} / \mathrm{l}(23-63 \%$ before islet transplantation, $0-21 \%$ after transplantation).

Achievement of better metabolic control after islet transplantation appeared to be mainly influenced by the islet mass infused, and it seemed to be independent of donor characteristics (Table 3 ) or of residual endogenous $\mathrm{C}$ peptide, the level of which did not correlate with the reduction in insulin requirement or with insulin independence until the porcine graft was functional.

The negative response of primate C-peptide to metabolic challenges, with a fall after the stimulus, as seen in diabetic monkeys (Fig. 2), also suggests that the residual islet mass was not able to contribute to the metabolic improvement. This was shown by the analysis of the IVGTTs performed after transplantation in four of the monkeys with a

Table 2 Mean metabolic values in monkeys before streptozotocin (healthy non-diabetic) and during the diabetic state

\begin{tabular}{|c|c|c|c|c|}
\hline \multirow[t]{2}{*}{ Monkey no. } & \multirow{2}{*}{$\begin{array}{l}\text { Before streptozotocin: non-diabetic state } \\
\text { Mean glucose }^{\mathrm{a}} \\
(\mathrm{mmol} / \mathrm{l})\end{array}$} & \multicolumn{3}{|c|}{ After streptozotocin: diabetic state } \\
\hline & & $\begin{array}{l}\text { Mean glucose }{ }^{\mathrm{a}} \\
(\mathrm{mmol} / \mathrm{l})\end{array}$ & $\begin{array}{l}\text { Glucose }>11.1 \mathrm{mmol} / 1^{\mathrm{b}} \\
(\%)\end{array}$ & $\begin{array}{l}\text { Mean insulin dosage } \\
\left(\mathrm{IU} \mathrm{kg} \mathrm{kgy}^{-1} \text { ) }\right.\end{array}$ \\
\hline 1 & $3.4(n=1)$ & $12.0 \pm 0.5(n=121)$ & $55(n=121)$ & $2.67 \pm 0.14(n=70)$ \\
\hline 3 & $3.2(n=1)$ & $13.1 \pm 0.3(n=185)$ & $77(n=185)$ & $2.17 \pm 0.11(n=95)$ \\
\hline 4 & $2.2(n=2)$ & $11.5 \pm 0.6(n=46)$ & $47(n=46)$ & $1.03 \pm 0.03(n=23)$ \\
\hline 5 & $2.9(n=2)$ & $10.2 \pm 0.8(n=37)$ & $51(n=37)$ & $0.58 \pm 0.03(n=21)$ \\
\hline 6 & $3.3(n=2)$ & $13.0 \pm 0.9(n=30)$ & $73(n=30)$ & $0.75 \pm 0.05(n=15)$ \\
\hline $2^{\mathrm{c}}$ & $4.6(n=1)$ & $10.7 \pm 0.7(n=54)$ & $48(n=54)$ & $2.25 \pm 0.10(n=60)$ \\
\hline $7^{\mathrm{c}}$ & $3.9(n=1)$ & $13.4 \pm 1.6(n=28)$ & $59(n=28)$ & $0.46 \pm 0.02(n=14)$ \\
\hline $8^{c}$ & $3.9 \pm 0.2(n=5)$ & $9.1 \pm 1.0(n=28)$ & $32(n=28)$ & $0.96 \pm 0.03(n=14)$ \\
\hline $9^{c}$ & $2.9 \pm 0.2(n=4)$ & $8.2 \pm 0.5(n=86)$ & $23(n=86)$ & $0.80 \pm 0.02(n=43)$ \\
\hline $10^{\mathrm{c}}$ & $3.0 \pm 0.1(n=6)$ & $12.9 \pm 0.9(n=30)$ & $63(n=30)$ & $1.04 \pm 0.07(n=15)$ \\
\hline
\end{tabular}

Data are means $\pm \mathrm{SE}$, with number of observations in parentheses.

${ }^{a}$ Mean glucose is the average of morning and evening levels.

${ }^{\mathrm{b}}$ Percentage of glucose measurements above $11.1 \mathrm{mmol} / \mathrm{l}$ for each animal.

${ }^{\mathrm{c}}$ Monkeys 2, 7, 8, 9 and 10 showed an improvement in metabolic control. 
Table 3 Mean metabolic values in monkeys after porcine islet transplantation

\begin{tabular}{|c|c|c|c|c|c|c|c|}
\hline $\begin{array}{l}\text { Monkey } \\
\text { no. }\end{array}$ & $\begin{array}{l}\text { Type of } \\
\text { donor pig }\end{array}$ & $\mathrm{IEq} / \mathrm{kg}$ & $\begin{array}{l}\text { Mean glucose }{ }^{a} \\
(\mathrm{mmol} / \mathrm{l})\end{array}$ & $\begin{array}{l}\text { Glucose } \\
>11.1 \mathrm{mmol} / 1^{\mathrm{b}} \\
(\%)\end{array}$ & $\begin{array}{l}\text { Mean insulin } \\
\left(\mathrm{IU} \mathrm{kg}{ }^{-1} \text { day }^{-1}\right)\end{array}$ & $\begin{array}{l}\text { Porcine } \\
\text { C-peptide } \\
(\mathrm{nmol} / \mathrm{l})\end{array}$ & $\begin{array}{l}\text { Follow-up after } \\
\text { transplantation } \\
\text { (days) }\end{array}$ \\
\hline 1 & Wild-type & 40000 & $\begin{array}{c}10.9 \pm 0.4 \\
(n=79)\end{array}$ & $46(n=79)$ & $\begin{array}{c}1.38 \pm 0.10(52 \%) \\
(n=39)\end{array}$ & $\begin{array}{c}0.18 \pm 0.04 \\
(n=16)\end{array}$ & $39^{\mathrm{g}}$ \\
\hline $3^{\mathrm{f}}$ & - & - & - & - & - & - & - \\
\hline 4 & GGTA1-DKO & 40000 & $\begin{array}{r}9.4 \pm 1.0 \\
(n=15)\end{array}$ & $27(n=15)$ & $\begin{array}{l}1.28 \pm 0.29(124 \%) \\
(n=8)\end{array}$ & $\begin{array}{c}0.11 \pm 0.02 \\
(n=5)\end{array}$ & $8^{\mathrm{i}}$ \\
\hline 5 & GGTA1-DKO & 47000 & $\begin{array}{c}9.8 \pm 0.8 \\
(n=36)\end{array}$ & $35(n=36)$ & $\begin{array}{l}3.05 \pm 0.51(521 \%) \\
\quad(n=19)\end{array}$ & $\begin{array}{c}0.07 \pm 0.02 \\
(n=11)\end{array}$ & $19^{\mathrm{h}}$ \\
\hline 6 & GGTA1-DKO & 40000 & $\begin{array}{c}15.8 \pm 0.4 \\
(n=236)\end{array}$ & $76(n=236)$ & $\begin{array}{l}2.20 \pm 120(293 \%) \\
(n=120)\end{array}$ & $\begin{array}{c}0.04 \pm 0.01 \\
(n=21)\end{array}$ & $120^{\mathrm{h}}$ \\
\hline $2^{\mathrm{e}}$ & Wild-type & 46000 & $\begin{array}{l}8.8 \pm 0.3 \\
\quad(n=118)\end{array}$ & $21(n=118)$ & $\begin{array}{l}0.50 \pm 0.06(22 \%) \\
\quad(n=60)\end{array}$ & $\begin{array}{c}0.26 \pm 0.03 \\
(n=25)\end{array}$ & $60^{\mathrm{g}}$ \\
\hline $7^{\mathrm{e}}$ & Wild-type & 100000 & $\begin{array}{c}6.8 \pm 2.1 \\
(n=13)\end{array}$ & $7(n=13)$ & $\begin{array}{l}0.06 \pm 0.05(13 \%) \\
(n=8)\end{array}$ & $\begin{array}{c}0.93 \pm 0.19 \\
(n=5)\end{array}$ & $8^{\mathrm{i}}$ \\
\hline $8^{\mathrm{d}, \mathrm{e}}$ & Wild-type & 95000 & $\begin{array}{c}5.3 \pm 0.16 \\
(n=84)\end{array}$ & $0(n=84)$ & $\begin{array}{l}0.04 \pm 0.01(4 \%) \\
(n=43)^{\mathrm{d}}\end{array}$ & $\begin{array}{c}0.21 \pm 0.05 \\
(n=13)\end{array}$ & $43^{\mathrm{h}}$ \\
\hline $9^{e}$ & GGTA1-DKO & 77000 & $\begin{array}{c}8.5 \pm 0.3 \\
(n=40)\end{array}$ & $7(n=40)$ & $\begin{array}{l}0.35 \pm 0.03(44 \%) \\
(n=21)\end{array}$ & $\begin{array}{c}0.32 \pm 0.03 \\
(n=6)\end{array}$ & $21^{\mathrm{h}}$ \\
\hline $10^{\mathrm{d}, \mathrm{e}}$ & GGTA1-DKO & 100000 & $\begin{array}{r}6.8 \pm 0.4 \\
(n=73)\end{array}$ & $7(n=73)$ & $\begin{array}{c}0.15 \pm 0.07(14 \%) \\
(n=39)^{\mathrm{d}}\end{array}$ & $\begin{array}{c}0.28 \pm 0.07 \\
(n=8)\end{array}$ & $39^{\mathrm{i}}$ \\
\hline
\end{tabular}

Data are means $\pm \mathrm{SE}$, with number of observations in parentheses.

${ }^{a}$ Mean glucose represents the average of morning and evening levels.

${ }^{\mathrm{b}}$ Percentage of glucose measurements above $11.1 \mathrm{mmol} / \mathrm{l}$ obtained in each animal.

${ }^{c}$ Mean insulin dosage after transplantation is the absolute value; percentage of the dosage before transplantation is given in parentheses.

${ }^{\mathrm{d}}$ Insulin therapy was discontinued 2 weeks after porcine islet transplantation in monkeys 8 and 10 .

${ }^{\mathrm{e}}$ Monkeys 2, 7, 8, 9 and 10 showed an improvement in metabolic control.

${ }^{\mathrm{f}}$ Monkey 3 was not transplanted because of intolerance to immunosuppressive drugs.

Reasons for end of follow-up: ${ }^{\mathrm{g}}$ electively killed for undetectable graft function; ${ }^{\mathrm{h}}$ loss of vascular lines; ${ }^{\mathrm{i}}$ killed for clinical reasons (severe anaemia, gastric dilatation)

functioning graft. On the contrary, although none of these IVGTTs were completely normal $\left[K_{\mathrm{G}}\right.$ ranged from 1.09 $3.04 \mathrm{mmol} \mathrm{l}^{-1} \mathrm{~min}^{-1}$ (mean $1.60 \pm 0.30 \mathrm{mmol} \mathrm{l}^{-1} \mathrm{~min}^{-1}$ ), below the normal values $(p<0.001)$ ], a clear porcine Cpeptide response was indeed seen (Fig. 4).

\section{Discussion}

During the last 6 years, clinical trials of allotransplantation of pancreatic islets from deceased donors have supplied sufficient insulin to abrogate the need for exogenous insulin in patients with type 1 diabetes, at least for a limited period [1]. Even if the control of diabetes was not complete, islet transplantation was able to improve the management of unstable type 1 diabetes $[1,35]$.

One of the problems presented by these recent clinical trials is that two to three pancreases are needed to provide an islet mass sufficient to establish normal metabolic control in the majority of patients. Furthermore, following transplantation, a number of mechanisms, only partially understood, contribute to a gradual but eventually complete loss of islet mass $[1,35]$. Both of these observations render the availability of deceased organ donors even more insufficient in relation to the number of diabetic patients who might benefit from this therapy. Besides the attention being devoted to the search for strategies to reduce human islet cell loss after transplantation, thus prolonging their function, it would be beneficial to be able to transplant animal islets, as these would provide a virtually unlimited source for clinical needs.

Pigs have been considered as possible sources of islets for transplantation because of the similarity between human and porcine insulin, the number of available islets per animal, and ethical acceptability [36, 37].

Preclinical studies are necessary to test the ability of pig islets to work in vivo in a recipient of a species similar to humans. In this regard, recent data indicate that wild-type neonatal or adult pig islets can survive for weeks in monkey recipients [2,3]. One of these studies [3], as well as our own studies [4, 16], were performed in cynomolgus monkeys. These Old World monkeys represent a good model for islet transplantation studies $[3,7,36]$. They can 
Fig. 3 Porcine C-peptide levels and exogenous insulin requirements in diabetic monkeys after porcine islet transplantation. a Porcine C-peptide levels in most monkeys with improved metabolic control (red lines) were higher than in monkeys that demonstrated no improvement in metabolic control (blue lines). The C-peptide level in monkeys with improved metabolic control was generally $>0.20 \mathrm{nmol} / 1$. b Insulin requirement in transplanted monkeys with mean porcine C-peptide $>0.20 \mathrm{nmol} /$ 1 (red lines) was lower than that in monkeys with mean porcine C-peptide $<0.20 \mathrm{nmol} / \mathrm{l}$ (blue lines). The insulin requirement in the majority of monkeys with a mean porcine $\mathrm{C}$-peptide level of $>0.20 \mathrm{nmol} / 1$ was $<0.5 \mathrm{IU}$ $\mathrm{kg}^{-1}$ day $^{-1}$

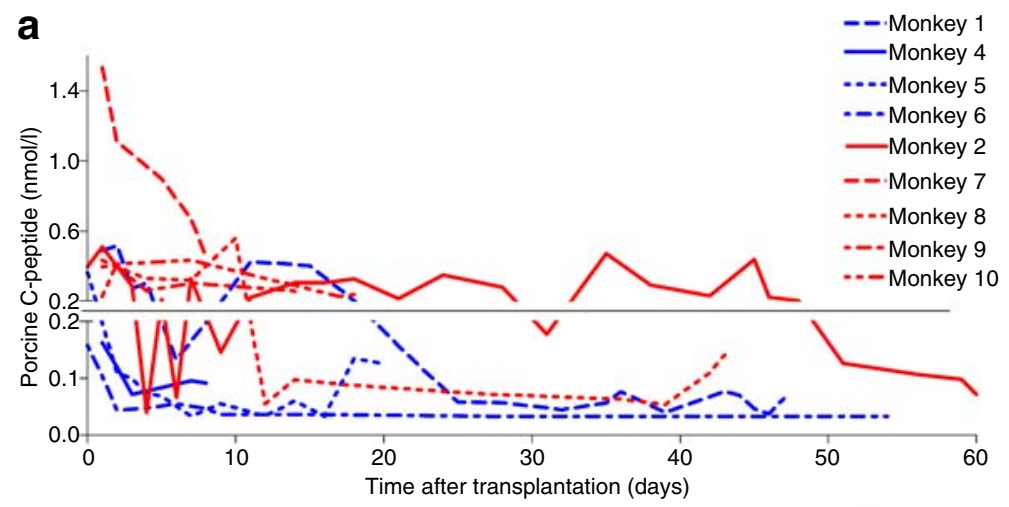

b

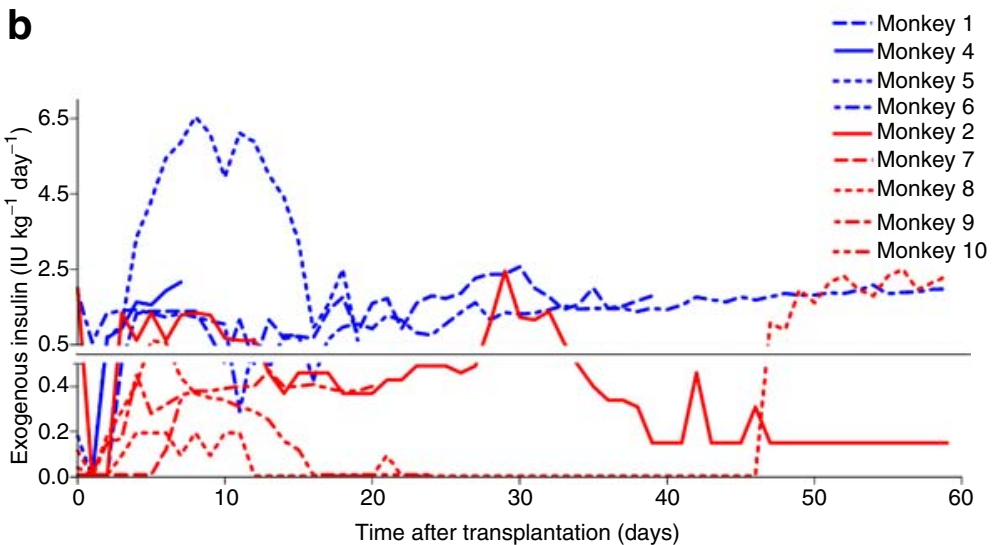

be rendered diabetic by the administration of streptozotocin $[7,16,38,39]$ or by total pancreatectomy $[2,40]$, and prior to islet transplantation the induced diabetes can be controlled by insulin injections for long periods of time.

The pig-to-monkey transplantation model presents immunological incompatibilities and it therefore remains a good model to study the immunological aspects of islet xenotransplantation. On the other hand, relevant metabolic differences between the two animal species may have an impact on the outcome of islet transplantation, not only in this model but also, more importantly, in clinical applications of the future. This appears to be particularly important when parameters such as blood glucose levels, C-peptide levels and insulin levels are used to monitor the xenograft function.

In the present study we investigated differences in metabolism relating to glucose homeostasis in monkeys and pigs and in the pig-to-monkey islet transplantation setting. The purpose was to identify metabolic parameters that can aid in monitoring and evaluating the success of islet xenotransplantation, and thus aid in translating this model into clinical practice. The data we present clearly demonstrate differences in metabolic parameters between cynomolgus monkeys and pigs. Monkeys are characterised by high circulating C-peptide and insulin levels and by low glucose levels, observations that concur with those reported previously by others [5-8]. On the other hand, pigs exhibit low C-peptide and insulin levels and higher blood glucose levels $[9,10]$. Although both species responded to glucose and food stimulation, differences in insulin output and glucose homeostasis were also noted. The relatively poor response of pig islets to glucose is well known in vitro, where, however, it does not seem to be due to alterations in glucose sensing or metabolism [11]. The molecular differences in porcine and monkey C-peptide and insulin are not substantial, but these differences may interfere in their kinetics and in vivo activity. Human and porcine insulins, however, have demonstrated equivalent therapeutic activity [41].

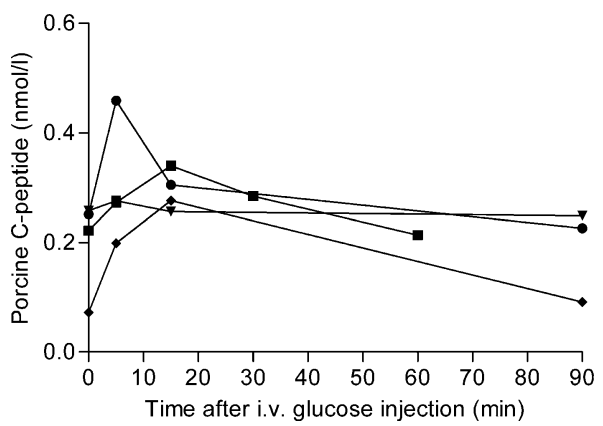

Fig. 4 Porcine C-peptide responses to IVGTT in four monkeys that showed an improvement in metabolic control after porcine islet transplantation. The IVGTTs were performed on postoperative day 46 in monkey 2 (squares), 27 in monkey 8 (diamonds), 21 in monkey 9 (triangles) and 24 in monkey 10 (circles) 
When target glucose levels were similar and the same insulin formulation used, we observed that exogenous s.c. insulin requirements in diabetic pigs $\left(0.67 \pm 0.05 \mathrm{IU} \mathrm{kg}^{-1} \mathrm{day}^{-1}\right.$ to maintain a mean blood glucose of $12.4 \pm 2.3 \mathrm{mmol} / 1 ; n=3$ ) were lower than in diabetic monkeys $\left(1.92 \pm 0.20 \mathrm{IU} \mathrm{kg}^{-1} \mathrm{day}^{-1}\right.$ to maintain a mean blood glucose concentration of $14.7 \pm$ $1.0 \mathrm{mmol} / \mathrm{l} n=4)$. In this respect, human requirements are between those of pigs and monkeys. This may be of importance in respect to the eventual transfer of pig islet transplantation into clinical practice, since human insulin demands are lower than those of the monkeys [42].

Sustained normoglycaemia in the monkey is associated with endogenous $\mathrm{C}$-peptide levels ranging from 0.47 to $3.14 \mathrm{nmol} / 1$; in pigs the range is between 0.11 and $0.32 \mathrm{nmol} / \mathrm{l}$. In the pig-to-monkey islet transplantations, monkeys with porcine C-peptide levels within the normal range for nondiabetic pigs but below normal for monkeys showed an improvement in gluco-metabolism, with insulin independence seen in some cases. Nevertheless, beta cell function associated with higher porcine C-peptide levels should be expected to stably normalise a diabetic monkey. Based on the metabolic performance of porcine islet grafts in our monkey recipients, we estimate that porcine C-peptide levels of at least $0.47 \mathrm{nmol} / 1$ should be reached to achieve protracted normalisation. Again, since the normal C-peptide range in a nondiabetic human is lower than that in a monkey, the metabolic demand on pig islet grafts should be lower in a clinical application. The improved metabolic control obtained in monkey recipients following pig islet transplantation was associated with relatively low levels of porcine C-peptide. In particular, we found that a concentration of porcine C-peptide of $0.20 \mathrm{nmol} / \mathrm{l}$ provided a threshold for significant improvement. Thus, low levels may be sufficient to prevent chronic complications, as also observed in diabetic patients with residual C-peptide production or in partially functioning islet transplants [1, 43-45].

The data suggest that the level of graft function (evaluated by the measurement of C-peptide levels) necessary to normalise blood glucose in the recipient is determined by the recipient levels rather than by the donor levels. Considering the metabolic target of humans and the performance of pig islets in primates, whose metabolic demand is higher than that of pigs and, more importantly, higher than that of humans, we can conclude that a good metabolic outcome could be reached in humans.

Islet xenotransplantation is still in an experimental phase and requires further exploration. Observations from preclinical models suggest that, in addition to immunological aspects linked to species differences, metabolic differences between donor and recipient species are important matters for further investigation and may be key to the success of islet xenotransplantation. An in-depth study of this will aid our understanding of the dynamics of insulin-producing islet cells and may facilitate the translation of islet xenotransplantation into clinical trials.

Acknowledgements We gratefully acknowledge the help of P.P.M. Rood, C. Knoll, A. Sands, A. Funair and A. Styche. We also thank the following surgeons: N. Murase, X. Zhu, Y. Zhu, M. Ezzelarab, H.-C. Tai and Y. J. Lin. This work was supported in part by Juvenile Diabetes Research Foundation grant no. 4-2004-786, Department of Defense grant no. W81XWH-06-1-0317 and American Diabetes Association grant no. 1-04-RA-15.

Duality of interest The authors declare that there is no duality of interest associated with this manuscript.

\section{References}

1. Shapiro AM, Ricordi C, Hering BJ et al (2006) International trial of the Edmonton protocol for islet transplantation. N Engl J Med 355:1318-1330

2. Cardona K, Korbutt GS, Milas Z et al (2006) Long-term survival of neonatal porcine islets in nonhuman primates by targeting costimulation pathways. Nat Med 12:304-306

3. Hering BJ, Wijkstrom M, Graham ML et al (2006) Prolonged diabetes reversal after intraportal xenotransplantation of wild-type porcine islets in immunosuppressed nonhuman primates. Nat Med 12:301-303

4. Rood P, Bottino R, Balamurugan AN et al (2007) Reduction of early graft loss after intraportal porcine islet transplantation in monkeys. Transplantation 83:202-210

5. Cameron JL, Koerker DJ, Steiner RA (1985) Metabolic changes during maturation of male monkeys: possible signals for onset of puberty. Am J Physiol 249:E385-E391

6. Honjo S, Kondo Y, Cho F (1976) Oral glucose tolerance test in the cynomolgus monkey (Macaca fascicularis). Lab Anim Sci 26:771-776

7. Koulmanda M, Qipo A, Chebrolu S, O’Neil J, Auchincloss H, Smith RN (2003) The effect of low versus high dose of streptozotocin in cynomolgus monkeys (Macaca fascicularis). Am J Transplant 3:267-272

8. Litwak KN, Cefalu WT, Wagner JD (1998) Streptozotocininduced diabetes mellitus in cynomolgus monkeys: changes in carbohydrate metabolism, skin glycation, and pancreatic islets. Lab Anim Sci 48:172-178

9. Kobayashi K, Kobayashi N, Okitsu T et al (2004) Development of a porcine model of type 1 diabetes by total pancreatectomy and establishment of a glucose tolerance evaluation method. Artif Organs 28:1035-1042

10. Shokouh-Amiri MH, Rahimi-Saber S, Andersen HO, Jensen SL (1996) Pancreas autotransplantation in pig with systemic or portal venous drainage. Effect on the endocrine pancreatic function after transplantation. Transplantation 61:1004-1009

11. Rabuazzo AM, Davalli AM, Buscema M et al (1995) Glucose transport, phosphorylation, and utilization in isolated porcine pancreatic islets. Metabolism 44:261-266

12. Phelps CJ, Koike C, Vaught TD et al (2003) Production of alpha 1,3-galactosyltransferase-deficient pigs. Science 299:411-414

13. Tigno XT, Gerzanich G, Hansen BC (2004) Age-related changes in metabolic parameters of nonhuman primates. J Gerontol A Biol Sci Med Sci 59:1081-1088

14. McCulloch DK, Koerker DJ, Kahn SE, Bonner-Weir S, Palmer JP (1991) Correlations of in vivo beta-cell function tests with beta-cell mass and pancreatic insulin content in streptozocin-administered baboons. Diabetes 40:673-679 
15. Ward WK, Bolgiano DC, McKnight B, Halter JB, Porte D Jr (1984) Diminished B cell secretory capacity in patients with noninsulindependent diabetes mellitus. J Clin Invest 74:1318-1328

16. Rood PP, Bottino R, Balamurugan AN et al (2006) Induction of diabetes in cynomolgus monkeys with high-dose streptozotocin: adverse effects and early responses. Pancreas 33:287-292

17. Expert Committee on the Diagnosis and Classification of Diabetes Mellitus (1997) Report of the Expert Committee on the Diagnosis and Classification of Diabetes Mellitus. Diabetes Care 20:11831197

18. Bottino R, Balamurugan AN, Smetanka $C$ et al (2007) Isolation outcome and functional characteristics of young and adult pig pancreatic islets for transplantation studies. Xenotransplantation 14:74-82

19. Greenspan FS, Gardner DG (2006) Normal hormone reference ranges. In: Greenspan FS, Gardner DG (eds) Basic and clinical endocrinology, 7th edn. McGraw-Hill Companies, New York, pp 920-938

20. Genuth S, Alberti KG, Bennett P et al (2003) Follow-up report on the diagnosis of diabetes mellitus. Diabetes Care 26:3160-3167

21. World Health Organization (1999) Definition, diagnosis and classification of diabetes mellitus and its complications. Report of a WHO consultation. Part 1: diagnosis and classification of diabetes mellitus. Available from http://www.staff.ncl.ac.uk/philip. home/who_dmc.htm, last accessed in September 2007

22. Alberti KG, Zimmet PZ (1998) Definition, diagnosis and classification of diabetes mellitus and its complications. Part 1: diagnosis and classification of diabetes mellitus. Provisional report of a WHO consultation. Diabet Med 15:539-553

23. D'Orazio P, Burnett RW, Fogh-Andersen N et al (2005) Approved IFCC recommendation on reporting results for blood glucose (abbreviated). Clin Chem 51:1573-1576

24. Bakalov VK, Cooley MM, Quon MJ et al (2004) Impaired insulin secretion in the Turner metabolic syndrome. J Clin Endocrinol Metab 89:3516-3520

25. Breda E, Cobelli $C$ (2001) Insulin secretion rate during glucose stimuli: alternative analyses of C-peptide data. Ann Biomed Eng 29:692-700

26. Kjems LL, Volund A, Madsbad S (2001) Quantification of betacell function during IVGTT in type II and non-diabetic subjects: assessment of insulin secretion by mathematical methods. Diabetologia 44:1339-1348

27. Monauni T, Zenti MG, Cretti A et al (2000) Effects of glucosamine infusion on insulin secretion and insulin action in humans. Diabetes 49:926-935

28. Nyholm B, Porksen N, Juhl CB et al (2000) Assessment of insulin secretion in relatives of patients with type 2 (non-insulindependent) diabetes mellitus: evidence of early beta-cell dysfunction. Metabolism 49:896-905

29. Overgaard RV, Jelic K, Karlsson M, Henriksen JE, Madsen H (2006) Mathematical beta cell model for insulin secretion following IVGTT and OGTT. Ann Biomed Eng 34:1343-1354

30. Vicini P, Zachwieja JJ, Yarasheski KE, Bier DM, Caumo A, Cobelli C (1999) Glucose production during an IVGTT by deconvolution: validation with the tracer-to-tracee clamp technique. Am J Physiol 276:E285-E294

31. Dalla Man C, Campioni M, Polonsky KS et al (2005) Two-hour seven-sample oral glucose tolerance test and meal protocol: minimal model assessment of beta-cell responsivity and insulin sensitivity in nondiabetic individuals. Diabetes 54:3265-3273

32. Larsson H, Ahren B (1998) Glucose-dependent arginine stimulation test for characterization of islet function: studies on reproducibility and priming effect of arginine. Diabetologia 41:772-777

33. Rickels MR, Schutta MH, Markmann JF, Barker CF, Naji A, Teff KL (2005) $\beta$-Cell function following human islet transplantation for type 1 diabetes. Diabetes 54:100-106

34. Marena S, Montegrosso G, De Michieli F, Pisu E, Pagano G (1992) Comparison of the metabolic effects of mixed meal and standard oral glucose tolerance test on glucose, insulin and Cpeptide response in healthy, impaired glucose tolerance, mild and severe non-insulin-dependent diabetic subjects. Acta Diabetol 29:29-33

35. Ryan EA, Paty BW, Senior PA et al (2005) Five-year follow-up after clinical islet transplantation. Diabetes 54:2060-2069

36. Rood PP, Buhler LH, Bottino R, Trucco M, Cooper DK (2006) Pig-to-nonhuman primate islet xenotransplantation: a review of current problems. Cell Transplant 15:89-104

37. Rother KI, Harlan DM (2004) Challenges facing islet transplantation for the treatment of type 1 diabetes mellitus. J Clin Invest 114:877-883

38. Tal MG, Hirshberg B, Neeman $Z$ et al (2004) Induction of diabetes in nonhuman primates by means of temporary arterial embolization and selective arterial injection of streptozotocin. Radiology 230:163-168

39. Theriault BR, Thistlethwaite JR Jr, Levisetti MG et al (1999) Induction, maintenance, and reversal of streptozotocin-induced insulin-dependent diabetes mellitus in the juvenile cynomolgus monkey (Macaca fascicularis). Transplantation 68:331-337

40. Ericzon BG, Wijnen RM, Kubota K, vd Bogaard A, Kootstra G (1991) Diabetes induction and pancreatic transplantation in the cynomolgus monkey: methodological considerations. Transpl Int 4:103-109

41. Richter B, Neises G (2003) 'Human' insulin versus animal insulin in people with diabetes mellitus. Cochrane Database Syst Rev: CD003816

42. International Society for Pediatric and Adolescent Diabetes (2000) ISPAD consensus guidelines for the management of type 1 diabetes mellitus in children and adolescents. Consensus guidelines 2000. Available from http://www.diabetesguidelines.com/ health/dwk/pro/guidelines/ISPAD/ispad.asp, last accessed in September 2007

43. Diabetes Control and Complications Trial Research Group (1998) Effect of intensive therapy on residual beta-cell function in patients with type 1 diabetes in the diabetes control and complications trial. A randomized, controlled trial. The Diabetes Control and Complications Trial Research Group. Ann Intern Med 128:517-523

44. Fiorina P, Folli F, Bertuzzi F et al (2003) Long-term beneficial effect of islet transplantation on diabetic macro-/microangiopathy in type 1 diabetic kidney-transplanted patients. Diabetes Care 26:1129-1136

45. Fiorina P, Gremizzi C, Maffi P et al (2005) Islet transplantation is associated with an improvement of cardiovascular function in type 1 diabetic kidney transplant patients. Diabetes Care 28:1358-1365 